https://doi.org/10.18485/iipe_postsovjet.2021.ch1

Душко Димитријевић

\title{
СЕЦЕСИОНИСТИЧКИ ПРОЦЕСИ \\ - ФАКТОРИ ОЧУВАҢА ИЛИ НАРУШАВАЊА МИРА И БЕЗБЕДНОСТИ НА ПРОСТОРУ БИВШЕГ СССР-а
}

\begin{abstract}
Ancтракт: Крај Хладног рата окончао је дугогодишње супарништво између Истока и Запада, а са њиме и седамдесетогодишњи идеолошки спор у којем је капитализам однео победу над комунизмом. Трансформисана глобална хијерархија довела је до нове политичке неравнотеже, која је за последицу имала не само бујање национализма, нетрпељивости, већ и освете и политичког ревизионизма. Нови светски поредак означио је крај великих социјалистичких федерација, пре свега Савеза Совјетских Социјалистичких Република (СССР), који је с почетка деведесетих година 20. века ушао у процес државног распада (дисолуције). Дисолуција СССР-а била је последица „мањевише" мирних сукцесивних сецесија, које су in fine довеле до нестанка совјетске државе и формирања Заједнице независних држава (ЗНД). У студији која следи, износе се одговарајућа објашњења о развоју совјетске државности и политичким процесима који су условили сукцесивне сецесије и стицање независности бивших Совјетских Социјалистичких Република (ССР). Студија садржи и међународноправну анализу о недоследној примени права на самоопредељење, која је на подручјима неких од нових независних држава довела до центрифугалних политичких процеса и до тзв. рекурзивних сецесија које су узроковале стварање de facto ентитета и зона „замрзнутих конфликта“, које латентно прете да угрозе међународни мир и безбедност.
\end{abstract}

Кључне речи: СССР, сецесија, дисолуција, рекурзивна сецесија, de facto државни ентитети, зоне замрзнутих конфликата, мир и безбедност

\footnotetext{
${ }^{1}$ Институт за међународну политику и привреду, Београд. dimitrijevicd@diplomacy.bg.ac.rs. Рад је настао у оквиру научноистраживачког пројекта: „Србија и изазови у међународним односима 2021. године“, који финансира Министарство просвете, науке и технолошког развоја Републике Србије, а реализује Институт за међународну политику и привреду током 2021. године.
} 


\section{Историјски осврт на успостављање СССР-а}

Од Октобарске револуције 1917. године, до пораза Руског царства 1921. године, трајао је период у којем је дошло до разградње некадашњег империјалног поретка и до успостављања новог облика друштвенополитичког система, којег је карактерисала совјетска идеолошка матрица о равноправности народа и сувереној једнакости држава. Успостављање новог поретка заснованог на поменутим начелима значило је успостављање федеративне заједнице у којој је могућ већи обим територијалне и политичке аутономије различитих националних и етничких група. Тако је, првим Уставом Руске Совјетске Федеративне Социјалистичке Републике (РСФСР), од 10. јула 1918, успостављена совјетска држава у коју је, поред Совјетске Социјалистичке Републике Русије (ССРР), ушло још и неколико аутономних совјетских социјалистичких република, аутономних региона и аутономних округа у којима су живеле неруске етничке заједнице. Постепено заузимање и других руских подручја од стране комунистичких оружаних снага довело је до успостављања совјетске револуционарне бољшевичке власти и до формирања сличних совјетских социјалистичких република по узору на РСФСР. Примера ради, 10. марта 1919. године, Седми конгрес Совјета Украјине усвојио је Устав по узору на РСФСР. У Белорусији је Први конгрес Совјета усвојио Устав у фебруару 1919. године. Совјетске социјалистичке републике биле су накратко формиране и у Литванији, Летонији и Естонији. На Кавказу, у Азербејџану и Јерменији, совјетске републике формиране су током 1920. године. Иако је Грузија дуго одолевала успостављању совјетске власти, и у њој је формирана совјетска република након продора совјетских оружаних трупа. Стицање статуса совјетске републике значило је за ове територије на Кавказу обавезу изградње уставног поретка. Тако је Азербејџан усвојио Устав 19. маја 1921, Јерменија 2. фебруара 1922. године, а Грузија 28. фебруара 1922. године. Пошто је РСФСР била доминантна сила над осталим совјетским републикама у политичком, војном, економском и демографском смислу, РСФСР је тежила да територијално обједини простор Белорусије, Украјине и Закавкаских совјетских република (Јерменије, Азербејџана и Грузије). У септембру 1922. године израђен је план о друштвено-политичком уређењу којим је предвиђено стапање ових република у РСФСР. Због отпора овај план није спроведен, али је током децембра дошло до усвајања Устава Закавкаске Совјетске Федеративне Социјалистичке Републике. На првом Конгресу 
Совјета, одржаном 30. децембра 1922. године, Русија, Белорусија, Украјина и Закавказје склапају Уговор и доносе Декларацију о заједници четири совјетске републике којим је створен Савез Совјетских Социјалистичких Република (СССР). Наредне године ови акти били су измењени другим Уставом СССР-а (тзв. Устав Лењина и Троцког). Текст о стварању СССР-а ратификовао је 31. јануара 1924. године други Конгрес Совјета. СССР се састојао од неколико савезних република са границама дефинисаним на основу „демографске расподеле народа“. Другим Уставом, формално је загарантован савез суверених и равноправних народа СССР-а. Совјетске републике су, према члану 4 Устава, имале формално право на сецесију. Такође, одредбама садржаним у Преамбули Устава, новим социјалистичким републикама омогућено је право да се придруже СССР-у.

Током двадесетих година 20. века, дошло је до многих територијалних промена и прекрајања граница унутар СССР-а (на пример, у оквиру РСФСР и Закавказја). Поред тога, створене су три нове совјетске социјалистичке републике - Туркменистан и Узбекистан (претходно у саставу РСФСР), а потом и Таџикистан (која је била одвојена од Узбекистана). Трећи совјетски Устав, усвојен је 5. децембра 1936. године (тзв. Стаљиинов Устав). ${ }^{2}$ Уставом је редефинисан статус савезних органа и Владе СССР-а. Ојачана је позиција централних власти према властима федералних јединица. Тиме је de facto извршена концентрација државних овлашћења у рукама руководства Комунистичке партије. Интереси СССР-а све су се више уклапали у интересе РСФСР-а. Према Уставу из 1936. године, број савезних република повећан је са седам на једанаест. Закавкаска Руска Совјетска Федеративна Социјалистичка Република (ЗРСФСР) била је расформирана, а Јерменија, Грузија и Азербејџан биле су интегрисане у СССР са статусом Совјетских Социјалистичких Република (ССР). Такође, у оквиру СССР-а биле су формиране две нове републике - Казахстан и Киргистан. Молдавска Аутономна Совјетска Социјалистичка Република (АССР), коју је СССР формирао 1924. године у саставу ССР Украјине, у августу 1940. године (након закључења Молотов-Рибентроп пакта о ненападању 1939. године), трансформисана је у ССР Молдавије. Исте године, балтичке државе Литванија, Летонија и Естонија, биле су анектиране и инкорпориране у СССР. Након окончања Другог светског рата, у октобру 1956. године, ССР

\footnotetext{
${ }^{2}$ Миодраг Јовичић, Велики уставни системи, елементи за једно упоредно уставно право, ИРО Светозар Марковић, Београд, 1984, стр. 222-234.
} 
Карелије (подручја које је некада било у саставу Финске и које је анектирано од СССР-а 1940. године), ушло је у састав РСФСР-а као АССР Карелија. Након поменутог периода, више нису вршене територијално-административне промене унутар СССР-а, све до његовог коначног распада. ${ }^{3}$

\section{Државно уређење СССР-а}

СССР је по свом дражавном устројству био пример велике федералне и мултинационалне државе, настале „слободним самоопредељењем и удруживањем једнаких Совјетских Социјалистичких Република“. У периоду након Другог светског рата федерално устројство државе није претрпело никакве структуралне промене. Све до 1990. године, СССР се састојао од петнаест федералних јединица: савезних република, аутономних република, аутономних области или региона и округа. Конституционално, СССР су представљале суверене републике. Њихова подручја административно су била подељена на области или регионе. Изузетак су представљале Летонија, Литванија, Естонија и Молдавија које су имале јединствену административно-територијалну структуру. Неке савезне републике (Русија, Грузија, Јерменија, Узбекистан и Таџикистан), имале су у свом саставу аутономне републике које су уживале одређени ниво самоуправе. Нека подручја у самој РСФСР - ССР Таџикистан, Грузија и Азербејџан - добила су статус аутономних области или регија.

Трећи совјетски Устав из 1936. године замењен је тек 7. октобра 1977, када је Врховни совјет СССР-а једногласно усвојио четврти и последњи совјетски Устав који је назван: „Основни закон Савеза Совјетских Социјалистичких Република“ (тзв. Брежњевљев Устав). У члану 70 став 1 Устава, СССР је формулисан као „интегрална, савезна и мултинационална држава настала на принципу социјалистичког федерализма, као резултат слободног самоопредељења народа и слободног удруживања равноправних Совјетских Социјалистичких Република“. Према члану 72 Устава, „свака Совјетска Социјалистичка Република задржала је право да

\footnotetext{
${ }^{3}$ Serge Thines, From Soviet federalism to the creation of the Commonwealth of Independent States, University of Luxembourg, CVCEeu, 2016, Internet: https://www.cvce.eu/obj/from_soviet _federalism_to_the_creation_of_the_commonwealth_of_independent_states_cis-encaa796f9-24fo-4e25-98da-4e98b20f18c8.html
} 
слободно иступи из СССР-а". ${ }^{4}$ Међутим, ово загарантовано право иступања из савеза није значило и „право на сецесију“, будући да је било само формално прокламовано и без адекватних институционалних механизама неопходних за његово остварење. У том смислу, право иступања или „право на сецесију“ имало је декларативну правну природу. Ово тим пре, јер једнопартијском и централизованом систему, какав је био СССР, сваки покушај нарушавања територијалног интегритета и политичке независности био је у зачетку санкционисан. ${ }^{5}$ Тек са окончањем Хладног рата, с почетка деведесетих година 20. века, дошло је до наговештаја укидања ограничења у погледу остваривања политичких права и грађанских слобода. То је нарочито било уочљиво пошто је ново комунистичко руководство, предвођено Михаилом Горбачовим, објавило „политику гласности и перестројке“. Поменута политика значила је отварање СССР-а према либералним и демократским вредностима западног света и реструктурирање целокупног политичког, правног и економског система. Иако се Горбачов надао да ће његова политика ревитализовати СССР, до тога ипак није дошло. Пад Берлинског зида 1989. године симболично је означио крај Хладнога рата, а то је за последицу имало урушавање СССР-а кроз низ сецесија његових ССР-а. Коначно, овакав исход довео је до државне дисолуције и настанка нових независних држава.

\section{Сецесија Совјетских Социјалистичких Република и распад СССР-а}

Са процесом окончања Хладног рата, совјетски комунистички режим није више био у стању да обузда политичке захтеве народа из различитих делова СССР-а. До тог периода подразумевало се да нико нема право да доводи у питање совјетско државно уређење. Политика партијског руководства природно је тежила да одржи социјалну кохезију, док је свака национална и етничка група стремила да учврсти сопствени статус и да обезбеди остварење својих политичких интереса. Водећи рачуна о

\footnotetext{
${ }^{4}$ John N. Hazard, Soviet Republics in International Law, in: R. Bernhardt (ed.), Encyclopedia of Public International Law, Max Planck Institute for Comparative Public Law and International Law, Amsterdam: North-Holland, 2002, para. 10.

${ }^{5}$ Theodor Schweisfurth, Soviet Union, Dissolution, in: R. Bernhardt (ed.), Ecyclopedia of Public International Law, Amsterdam: Elsevier, 2000, Vol. IV, pp. 530-531.
} 
партијским и државним приоритетима, руководство СССР-а се користило различитим средствима како би придобило што шире друштвене масе. У том смислу, руководство је финансијски подупирало своје симпатизере, а административно-територијалним јединицама је обезбеђивало различити степен културне аутономије. Делујући на сузбијању „претераног национализма" који је претио да децентрализује његове моћи, руководство СССР-а трудило се да не прекорачи уставом прописане границе, а што би могло имати негативне последице по његов статус. До средине осамдесетих година 20. века, совјетске власти успешно су потискивале сецесионистичке покрете, али већ од тог периода, због тешке економске и социјалне ситуације, стање се почело постепено мењати. Процес уставних реформи, започет у децембру 1988. године, означио је почетак дезинтеграције СССРа. Централне власти почеле су да попуштају а националистички покрети су све више јачали, да би временом добили значајно место у представничким телима, пре свега у Врховном Совјету. Из данашње перспективе може деловати донекле парадоксално, али је чињеница да је „демократизација совјетског режима“ довела до јачања центрифугалних политичких сила које су, позивајући се на уставом загарантована права из одредаба члана 70 и члана 72 Устава из 1977. године, захтевале већи обим политичке и територијалне аутономије, кроз значајан пренос државних надлежности. У неким случајевима то је значило не само истицање захтева за конституционалном реформом, већ и промоцију идеја о незавиности и националном ослобођењу.

Управо такав пример представљају три балтичке републике - Литванија, Летонија и Естонија, у којима је Горбачовљева реформистичка политика охрабрила унутрашње политичке снаге да се организују у „покрете за перестројку“, који ће мобилисати широке народне масе намерене да се отцепе од СССР-а. ${ }^{6}$ Преузимањем ефективне власти, влада Естоније објавила је декларацију о суверености 16. новембра 1988 године, којом је потврђено право нулификације свих прописа донетих за време совјетске власти. Сличне декларације донеле су владе Литваније, 26. маја 1989. године, и Летоније, 28. јула 1989. године. Иако су федералне власти СССР-а сматрале да је

\footnotetext{
${ }^{6}$ Mark R. Beissinger, "The intersection of Ethnic Nationalism and People Power Tactics in the Baltic States", in: Adam Roberts; Timothy Garton Ash (eds.), Civil resistance and power politics: the experience of non-violent action from Gandhi to the present, Oxford University Press, Oxford, 2009, pp. 231-246.
} 
уставом гарантовано право на самоопредељење совјетских република условљено политичким, економским, социјалним и правним чиниоцима, као и потребама и интересима самог СССР-а, све остале савезне републике (укључујући Русију, Белорусију, Украјину, Узбекистан, Казахстан, Грузију, Азербејџан, Молдавију, Киргистан, Таџикистан, Јерменију и Туркменистан), следиле су овакву праксу у периоду од 1989. до 1990. године, усвајајући декларације којим су знатно сужена овлашћења федералних власти над федералним јединицама. То је са конституционалног аспекта довело до сукцесивне сепарације од унутрашњег правног поретка СССР-а. ${ }^{7}$

Пошто је Конгрес совјетских народних депутата, крајем децембра 1989. године, утврдио да је тајни протокол уз Молотов-Рибентроп пакт о ненападању, закључен између СССР-а и нацистичке Немачке 1939. године, био супротан међународном праву јер је балтичке државе доделио совјетској сфери утицаја, литвански парламент је 11. марта 1990. године прогласио независност Литваније од СССР, усвајајући истовремено и политичке и правне акте којим је обновио своју државност. ${ }^{8}$ Наведени пример следиле су и друге две балтичке републике. Прво је Естонија, 30. марта 1990. године, донела декларацију којом се покреће процес иступања из СССР, да би потом и Летонија, 4. маја исте године, донела сличну декларацију којом се изражава жеља да се кроз законодавну процедуру спроведе сецесиони поступак. ${ }^{9}$ Сматрајући да је РСФСР као наследница Руског царства, у децембру 1918. године, признала суверенитет Литваније,

\footnotetext{
${ }^{7}$ За међународну праксу може бити занимљиво да Чеченија-Ингушетија и Татарстан нису донеле декларације о суверености, али је Чеченија 1. новембра 1991. године, једностраним проглашењем независности покушала насилно да се отцепи од Русије. Руска Федерација је употребом оружане силе успела да поврати територију под своју управу. Видети: Александар Павковић, Петар Радан, Стварање нових држава: Теорија и пракса отиепљења, Службени гласник, Београд, 2008, стр. 171-178; 210-216.

${ }^{8}$ На основу тајног протокола уз Молотов-Рибентроп пакта из 1939. године, који је Европу поделио на немачку и совјетску сферу утицаја, совјетска војска је у септембру 1939. године заузела источну Пољску. Естонија, Литванија и Летонија су стављене под притисак да прихвате одредбе уговора о успостављању војних совјетских база на њиховим територијама. Током јуна 1940. године, Црвена армија је окупирала све три балтичке државе успостављајући истовремено просовјетску власт. Током Другог светског рата, територија балтичких ССР је била окупирана од стране Немачке. Након тога, Совјети су поново заузели ова подручја уз прећутну сагласност западних савезника.

${ }^{9}$ Антонио Касезе, Самоодређење народа, Службени гласник, Београд, 2011, стр. 303.
} 
Летоније и Естоније, а да је потом СССР извршио протиправну анексију 1940. године, балтичке републике су истакле захтеве за државну рестаурацију и признање de iure међународноправног континуитета са раније независним државама са којима су биле у вези у периоду од 1920. до датума инкорпорације њихових подручја у СССР. СССР се није слагао са овим приступом, нити са донетим сецесионистичким акима. Наиме, СССР је сматрао да је инкорпорација подручја балтичких држава била у складу са принципом самоопредељења народа. Позивајући се на парламентарне прогласе балтичких држава од 21. јула 1940. године, којим се изражава сагласност са овим чином, совјетске власти су желеле да докажу његову легалност, уједно прећуткујући да су ови прогласи били резултат политичких притисака који нису били сагласни ни са унутрашњим, нити са међународним јавним правом. ${ }^{10}$ У намери да поништи ефекте донетих сепаратистичких аката, СССР је у јануару 1991. године покушао да ситуацију преокрене у своју корист употребом силе против Литваније, што му није пошло за руком. Да би осујетио даље бујање сепаратистичких снага, Горбачов је покушао да окупи републике око новог предлога уговора о федералном преуређењу СССР-а. Почетком марта 1991. године, објављен је предлог новог федералног уговора између република и СССР-а којим се изражава воља за очувањем и обновом савезне државе на демократским основама као Савеза Совјетских Суверених Република. Поводом овог питања одржан је референдум о будућности СССР-а 17. марта 1991. године у једанаест ССР-а и АССР Абхазији. Бирачко тело у девет ССР-а (РСФСР, Белорусији, Украјини, Азербејџану, Туркменистану, Узбекистану, Таџикистану, Казахстану и Киргистану), гласало је за Уговор о новом федералном савезу. Литванија, Естонија и Летонија, уз Молдавију, Јерменију и Грузију нису учествовале у овом референдуму. Три балтичке републике организовале су сопствене референдуме током фебруара и марта исте године, на којима се већина бирача определила за отцепљење од СССР-а. Референдум о независности одржан је и у Грузији 31. марта, у Молдавији 27. августа и Јерменији 21. септембра. Током 1991. године уследиле су и једностране декларације о независности Грузије (9. априла), Естоније (20. августа), Летоније (21. августа), Азербејџана (30. августа) и Јерменије (31.

\footnotetext{
${ }^{10}$ Romain Yakemtchouk, Les Républiques baltes en droit international. Echec d'une annexion opérée en violation du droit des gens, Annuaire Français de Droit International, 1991, No. 37, pp. 259-289.
} 
септембра). ${ }^{11}$ У августу је дошло до покушаја државног удара у Кремљу од стране конзервативних снага које су се залагале за очување СССР-а. Пошто пуч није успео, преостао је последњи покушај да се савезна држава преуреди на конфедералним основама. Међутим, ни овај покушај није био успешан јер су и друге републике СССР-а у међувремену прогласиле независност: Украјина - 24. августа, Белорусија - 25. августа, Молдавија 27. августа, Узбекистан и Киргистан - 31. августа, Таџикистан - 9. септембра, Туркменистан - 27. септембра и Казахстан - 16. децембра. Проглашавање независности отклонило је све препреке за отцепљење ССР-а од СССР-а, што је уз увођење либералних капиталистичких реформи довело до дефинитивног краха и распада совјетске федерације.

\section{Формирање Заједнице независних држава (ЗНД)}

Неуспех предлога о обнављању СССР-а довео је до састанка у Минску 8. децембра 1991. године, између председника Русије, Белорусије и Украјине. На састанку је усвојена декларација којом се констатује да је процес иступања република из СССР-а и формирање нових независних држава на њиховом подручју постала нова политичка реалност. У циљу успостављања новог облика федералних веза закључен је Споразум о оснивању Заједнице независних држава (ЗНД), којим је потврђено окончање важности Споразума о савезу из 1922. године, и de iure престанак СССР-а. ${ }^{12}$ У Споразуму о оснивању стране уговорнице истичу важност међусобног признања, поштовања

\footnotetext{
${ }^{11}$ Европска заједница је усвајањем декларације, од 27. августа 1991. године, признала независност балтичких држава. Следило је признање Сједињених Америчких Држава 4. септембра 1991. године, и признања свих осталих бивших совјетских савезних република 6. септембра 1991. године. Видети: Rein Müllerson, Law and Politics in the Recognition of New States, International Law: Rights and Politics, Routladgle, London, 1994, pp. 119-145; "The Continuity and Succession of States, by reference to the Former USSR and Yugoslavia", International and Comparative Law Quarterly, 1992, Vol. 42, p. 483; Rahim Kherad, "La reconnaissance internationale des Etats Baltes", Revue Generale de Droit International Public, 1992, No. 96, p. 843.

12 "Declaration by the Heads of State of the Republic of Belarus, the Russian Soviet Federative Socialist Republic; Agreement on the Establishment of the Commonwealth of Independent States, between the Republic of Belarus, the Russian Federation (RSFSR) and Ukraine", Minsk, 8 December 1991, International Legal Materials, 1992, No. 31, pp. 138-142.
} 
суверенитета, једнакости и немешања у унутрашње односе, одрицања од употребе силе, економских или других видова притисака. Државе гарантују једна другој право на самоопредељење и поштовање основних правила и принципа међународног права. У циљу развијања стабилних добросуседских односа и узајамне сарадње, Русија, Белорусија и Украјина потврђују своју приврженост поштовању Повеље УН, Хелсиншког завршног акта и других докумената ОЕБС-а. У Споразуму се посебно гарантује поштовање стандарда о заштити људских права и права мањина. ${ }^{13}$ Споразум предвиђа преузимање међународноправних обавеза из уговора СССР-а, чиме је принципијелно прихваћен принцип универзалне сукцесије. Овакво решење има нарочиту тежину у погледу осигурања међународног мира и безбедности у вези којег је прихваћена обавеза редуцирања војне силе и наоружања. ${ }^{14}$ Споразум не афектира права трећих држава и потврђује важност билатерално закључених уговора између страна уговорница. Свака страна уговорница задржала је право да обустави примену Споразума, о чему је дужна да писмено обавести друге стране уговорнице, годину дана унапред. ${ }^{15}$

Поводом закључења Споразума о оснивању ЗНД, упућен је истовремено позив свим другим републикама бившег СССР-а да приступе Заједници. На састанку у Алма-Ати, 21. децембра 1991. године, питање приступања решено је закључењем посебног Протокола. ${ }^{16}$ Протоколом се потврђује да

\footnotetext{
${ }^{13}$ Sergei A. Voitovich, "The Commonwealth of Independent States: An Emerging Institutional Model", European Journal of International Law, 1993, Vol. 4, No. 3, pp. 403-429.

${ }^{14}$ Западне силе су инсистирале да се све чланице раније федерације сматрају сукцесорима у погледу преузимања уговорних обавеза о контроли нуклеарног наоружања. Поред Русије, у овој групі земаља биле су и Белорусија, Украјина и Казахстан. Нарочито је занимљиво позивање на обавезе уговорене START аранжманом (Strategic Arms Reduction Talks). Посебним протоколом од 23. маја 1992. године, предвиђена је сукцесија свих ових споразума и уговорних аранжмана.

${ }^{15}$ Туркменистан је изашао из сталног чланства ЗНД-а 26. августа 2005. године, али је остао као придружени члан. Грузија је стекла придружено чланство у ЗНД-у у октобру 1992. године, али је након рата у Јужној Осетији напустила чланство 2009. године.

16 "Protocol to the Agreement on the Establishment of the Commonwealth of Independent States signed on December 8, 1991 at the city of Minsk, by the Republic of Belarus, the Russian Federation (RSFSR) and Ukraine, between the Republic of Azerbaijan, Republic of Armenia, Republic of Belarus, Republic of Kazakhstan, Russian Federation, Republic of Tajikistan, Turkmenistan, Republic of Uzbekistan and Ukraine," Alma-Ata, 21 December 1991, International Legal Materials, 1992, No. 31, p. 147.
} 
ће Споразум о оснивању ЗНД ступити на снагу у тренутку када га уговорне стране ратификују. ${ }^{17}$ Уједно, у декларацији донетој тим поводом, напомиње се да је оснивањем Заједнице СССР престао да постоји. ${ }^{18}$ Литванија, Летонија и Естонија одбиле су позив за приступањем ЗНД. Чланице Заједнице подржале су континуитет Русије у Уједињеним нацијама, укључујући и стално чланство у Савету безбедности и другим међународним организацијама. Процес признања држава окончан је пријемом у Уједињене нације 1992. године (изузимајући Белорусију и Украјину које су члански статус задржале одраније). ${ }^{19}$ Полазећи од правног оквира утврђеног Споразумом о оснивању ЗНД-а и других наведених аката, Русија и државе сукцесорке СССР-а, током 1991. и 1992. године, потписале су низ значајних докумената који се односе на преузимање права и обавеза СССР-а. ${ }^{20} \mathrm{Ha}$ новом самиту у Минску, 22. јануара 1993. године, донета је одлука којом је усвојена Повеља ЗНД. ${ }^{21}$ Повеља поставља институционалне оквире ЗНД-а на бази добровољног уједињења, поштовања историјских сличности, једнакости и равноправности страна и њиховог суверенитета, територијалног интегритета и политичке независности. ЗНД почива на

${ }^{17}$ Споразум о оснивању ЗНД ратифкован је следећим редоследом: Белорусија, 10. децембра 1991. године; Русија, 12. децембра 1991. године; Казахстан, 23. децембра 1991. године; Узбекистан, 4. јануара 1992. године; Јерменија, 18. фебруара 1992. године; Киргистан, 6. марта 1992. године; Таџикистан, 26. јуна 1993. године; Азербејџан, 24. септембра 1993. године; Грузија, 3. децембра 1993. године; Молдавија, 8. априла 1994. године; Украјина, 10. децембра 1999. године.

18 "Alma-Ata Declaration", International Legal Materials, 1992, No. 31, p. 149.

${ }^{19}$ Yehuda Z. Blum, "Russia takes over the Soviet Union's Seat at the United Nations", European Journal of International Law, 1992, Vol. 3, No. 2, pp. 354-363.

20 Деоба државне имовине по територијалном принципу није била могућа у случају стратешког наоружања, у вези кога су током 1992. године започети преговори о дислокацији на територију Русије. Неповерење Украјине у стварну намеру Русије да редукује арсенал наоружања, те бојазан да се исти складишти ради каснијег активирања, уз крајње осетљив проблем поделе Црноморске флоте лоциране на Кримском полуострву (Севастопољ), дефинитивно је пролонгирао решавање проблема сукцесије државне имовине. Видети: Љубивоје Првуловић, „Неки политички, војни и национални проблеми на тлу бившег Совјетског Савеза", Међународни проблеми, 1997, бр. 3-4, стр. 377-390; Душко Димитријевић, Међународно право сукцесије држава: Сукцесија државне имовине с посебним освртом на сукцесију СФР Југославије, Институт за међународну политику и привреду, Београд, 2007.

21 "Charter of the Commonwealth of Independent States", Minsk, 22 January 1993. 
пријатељским и добросуседским односима, међудржавној хармонији, поверењу, узајамном разумевању и сарадњи. Према Повељи „Заједница није држава и нема супранационалну моћ“. 22 Њена сврха састоји се у реализацији сарадње на политичком, економском, хуманитарном, културном и еколошком плану. Сарадња има за циљ свеопшти развој и интеграцију, тј. очување међународног мира и безбедности. Иако рецепира неке од стипулација садржаних у Споразуму о оснивању ЗНД, као што су поштовање Повеље УН, Хелсиншког завршног акта и других докумената ОЕБС-а, Повеља даје већи значај поштовању општих принципа и правила међународног права. ${ }^{23}$

\section{Правна природа сецесије од СССР-а}

Балтичке републике СССР-а нису се позивале на уставне одредбе о праву иступања из СССР-а, већ су своје право базирале искључиво на противправности совјетске анексије из 1940. године и на рестаурацији државноправног континуитета међународноправног субјективитета држава које су постојале све до момента инкорпорације њихових територија у совјетско државно подручје. Уз добијање међународног признања, ове републике су углавном мирним путем стекле своју независност. Остале републике СССР-а су, барем у почетној фази дезинтеграције државног јединства СССР-а, подвлачиле значај конституционалних одредби о иступању из федерације. Истине ради, ове одредбе су представљале само деклеративна начела, без јасно утврђене законске процедуре и институционалних механизама неопходних за легално остваривање „права на сецесију" и његову легитимизацију у државној пракси. Закон који је

\footnotetext{
22 Душко Димитријевић, „Настанак и функционисање међудржавних форума за сарадњу у Европи: један правни преглед", Драган Ђукановић (ур.), Међудржавни форуми у Eвponu, Институт за међународну политику и привреду, Београд, 2007, стр. 11-52.

23 Занимљиво је да је Украјина, као једна од држава оснивача ЗНД, одбила да ратификује Повељу. Незадовољна решењима постигнутим приликом сукцесије СССР-а, а потом и руском интервенцијом у сукобима на територији Донбаса (Доњецку и Луганску), као и приликом заузимања Крима, Украјина је 2014. године иступила из чланства ЗНД-а, али је већ наредне године изјавила да ће наставити да учествује у њеном раду на селективној основи. Од 2018. године, Украјина се повукла из рада свих извршних тела ЗНД. Видети: Illia Ponomarenko, "Ukraine withdraws all envoys from CIS bodies", Kyiv Post, 19 May 2018.
} 
усвојен у априлу 1990. године, од стране Врховног совјета СССР-а, а којим се прописивао поступак одржавања референдума о иступању из федерације, није представљао довољну гаранцију за остваривање права народа на самоопредељење до отцепљења, јер је закон предвиђао одржавање референдума на којем је требало постићи двотрећинску већину бирачког тела у републикама, уз почетну референдумску иницијативу Врховног совјета, или једне десетине совјетских грађана настањених у републици, и уз коначну потврду иступања од стране Конгреса народних депутата СССР-а у прелазном периоду од пет година (током којег би се морала решити сва отворена питања везана за сецесију). Притом, иступање је било лимитирано могућношћу да аутономна подручја унутар република имају право да остану у СССР-у уколико се остатак републике определи за сецесију. Овакво законодавно решење, уз недоследно дефинисање „народа“ који има право на самоопредељење унутар ССР-а, остављало је простора за арбитрарна тумачења и практично онемогућавање остваривања права на самоопредељење, а што је било у супротности са међународним правним стандардима. ${ }^{24}$ Штавише, законска решења су заоштрила постојећу политичку кризу, што је генерисало сукцесивне сецесије ССР-а од СССР-а. Републике СССР-а су, као што је раније поменуто, једна за другом одржавале референдуме како би легитимисале поступак стицања независности. Референдум је, према њиховом схватању, представљао начин за остварење права на самоопредељење. Међутим, остваривање овог права путем референдума било је крајње дискутабилно са аспекта легитимности, јер се референдумским изјашњавањем није водило довољно рачуна о вољи различитих етничких и националних заједница које нису представљале већинске народе у републикама, али које су према међународном праву такође имале право да захтевају да се изјасне о свом будућем политичком статусу, облику владавине, економском, социјалном и културном развоју и индивидуалном учешћу у вршењу власти. Ово тим пре, јер су према међународном праву начело равноправности и начело самоопредељења народа два међусобно допуњујућа дела исте норме чији значајан елемент представља слободно изражавање воље народа. У контексту одржавања и учвршћивања међународног мира и безбедности, ова два начела морала би остати комплементарна и у

\footnotetext{
${ }^{24}$ Касезе, ор.сіt., стр. 307, 315.
} 
случајевима настанка нових независних држава. ${ }^{25}$ Следствено произилази закључак да су фактицитет и разлози очувања стабилности, а не референдумско изјашњавање, играли одлучујућу улогу у постизању независности бивших совјетских република, а да је прихватање стања насталог након остваривања независности, суштински значило признање права већинских народа на спољашње самоопредељење, односно на одређивање сопственог међународноправног статуса. Остваривање самоопредељења осталих „народа“, унутар бивших совјетских република, требало је бити обезбеђено различитим облицима унутрашње самоуправе, аутономије или сличним политичким аранжманима који нису пружали „право на сецесију“.

\section{Поштовање територијалног statusa quo и међународно признање нових држава}

Да би се направио баланс између оправданих захтева за сецесијом и захтева за заштитом територијалног интегритета ССР-а, реализација права на самоопредељење била је повезана са питањем територијалног разграничења нових држава. С обзиром на то да је, према совјетској политичкој доктрини, територија представљала једну „флотантну“ категорију и границе између федералних јединица имале су само симболично значење. Међутим, конституционално одређење државне територије из члана 78 последњег совјетског Устава из 1977. године, указује да се територија република није могла мењати без њиховог пристанка, те да су се границе између ССР-а могле мењати искључиво уз њихову обострану сагласност. Коначну одлуку о промени граница између ССР доносила је савезна власт, што наводи на закључак да је савезна власт имала suprema leх да одлучује о промени унутрашњих граница. Будући да ова моћ није била остварива у случају сукцесивних сецесија ССР-а од СССР-а, право на самоопредељење било је условљено принципом uti possidetis juris који је раније примењиван у случајевима деколонизације бивших колонијалних

\footnotetext{
${ }^{25}$ Душко Димитријевић, „Међународноправни токови сецесије држава“, у: Јелена Перовић Вујачић, Унификација права и правна сигурност, Копаоничка школа природног права Слободан Перовић, Београд, 2020, стр. 353-378.
} 
подручја. ${ }^{26}$ Имајући у виду његову улогу у обезбеђењу стабилности (и када дође у конфликт с правом на самоопредељење), принцип uti possidetis juris, у случају отцепљења од СССР-а, требало је да послужи као обезбеђење територијалног statusa quo, тј. непромењивости постојећих граница у моменту стицања независности бивших совјетских република. Ако се изузму спорадични случајеви повратних сецесионистичких процеса, или тзв. рекурзивних сецесија унутар нових независних држава, његова примена је „колико-толико“ спречила избијање озбиљних међународних оружаних сукоба. Овакав приступ имао је и велики значај за добијање међународног признања. Наиме, међународно признање нових држава на простору бившег СССР-а било је условљено прихватањем општих демократских стандарда и њиховом инкорпорацијом у унутрашњи правни поредак. У том смислу, добар пример представља Европска заједница, која је 16. децембра 1991. године усвојила Смернице о признању нових држава у Источној Европи и Совјетском Савезу. Смерницама је утврђено да су државе наследнице СССР-а дужне да пре решавања статуса у водећим међународним организацијама прихвате међународне обавезе прописане у Повељи Уједињених нација, Хелсиншком Финалном акту из 1975. године и Париској Повељи из 1990. године. ${ }^{27}$ У конкретном случају, то је значило да бивше ССР након стицања независности имају обавезу поштовања принципа територијалног интегритета и неповредивости граница. Такође, ССР имају дужност да прихвате стандарде о владавини права, заштити људских и мањинских права, разоружању и регулисању последица сукцесије СССР-а у складу са принципима и правилима општег међународног права. Следствено наведеном, признање нових држава на постсовјетском простору постало је

26 "Frontier Dispute (Burkina Faso v. Mali)", International Court of Justice Reports, 1986, pp. 541, 586-587, para. 63; Alain Pellet, "The Opinions of the Badinter Arbitration Committee: A Second Breath for the Self-Determination of Peoples", European Journal of International Law 1992, Vol. 3, No. 1, pp. 178-185.

27 "Declaration on the Guidelines on the Recognition of New States in Eastern Europe and in the Soviet Union", UN Security Council Document S/23293, 17 December 1991, Annex II (1992), International Legal Materials, Vol. 31, pp. 1486, etc.; T. D. Grant, The Recognition of States: Law and Practice in Debate and Evolution, Praeger, Westport, 1999, p. 83; Roland Rich, "Recognition of States: The Collapse of Yugoslavia and the Soviet Union", European Journal of International Law, 1993, Vol. 4, No. 1, pp. 36-66. 
прејудицијелни политички чин којим се потврђивала њихова спремност за укључивањем у шире међународне односе. ${ }^{28}$

\section{Недоследна примена права на самоопредељење - узрок стварања de facto ентитета и зона „замрзнутих конфликата“}

Неуједначена примена права на самоопредељење, у случају сецесије од СССР-а, произилази из његове селективне примене. Наиме, право на самоопредељење признато је само већинским народима унутар ССР-а, а не свим народима који у њима живе. Потом, остваривање права на самоопредељење имало је секундарно значење у односу на прихваћени принцип о непроменљивости граница. Коначно, примена права на самоопредељење била је повезана са задржавањем територијалног statusa quo у моменту стицања независности, што је оставило отвореним питање остваривања права на самоопредељење других „народа“ (националних и етничких заједница које су углавном уживале одређени аутономни статус у бившим ССР-а). Немогућност измене наслеђених међурепубличких граница које су via facti претворене у државне границе, уз недоследну примену права на самоопредељење у оба његова вида - унутрашњем и спољашњем, довело је до озбиљних политичких спорова и до тзв. рекурзивних сецесија на подручјима нових држава, а што је проузроковало настанак de facto ентитета и зона „замрзнутих конфликата“. 29 Настанак de facto ентитета указују на неделотворност нових држава на подручју бившег СССР-а. Та неделотворност очитовала се најпре на унутрашњем плану, у немогућности остваривања права на самоопредељење одређених етничких заједница којима није пружена слобода избора политичког статуса, облика владавине, економског, социјалног и културног развоја. Поменути недостаци, уз бројне унутрашње и спољне интеракције, створили су прилику за сецесију која је

28 Душко Димитријевић, „Сецесија држава у доктрини и пракси међународног права“, у: Зоран Кнежевић, Коста Чавошки (уред.), Сецесија са становишта унутрашњег и међународног права и њене политичке последице, Српска академија наука и уметности, Београд, 2020, стр. 53-81.

${ }^{29}$ Antonello Trancredi, "Neither Athorized nor Prohibited? Secession and International Law after Kosovo, South Ossetia and Abkhazia", Italian Yearbook of International Law, 2008, No. 18, pp. 37-62. 
in concreto, била једна врста компензације (ремедијалног права)..$^{30}$ Међутим, невољност других држава да признају стање настало рекурзивним сецесијама, све док се томе супротставља матична држава, довела је до настанка de facto ентитета. Превођење оваквог de facto стања u de iure статус није могуће све док матична држава не да сагласност или не одустане од вршења суверених овлашћења на отцепљеном делу територије. ${ }^{31}$ Развој међународних политичких околности и реалних политичких услова, унутар држава на чијем подручјима је дошло до рекурзивних сецесија, одређиваће правац развоја сваке конкретне ситуације. До тада, међутим, de facto ентитети представљаће својеврсне зоне „замрзнутих конфликата“..2 у постсовјетској пракси, примера de facto ентитета и зона „замрзнутих

${ }^{30}$ Karl Doehring, "Self-Determination", in: Bruno Simma (ed.), The Charter of the United Nations: A Commentary, Oxford: University Press, 2002, Vol. I, para. 29; Christian Tomuschat, "Secession and Self-Determination", in: Marcelo G. Kohen (ed.), Secession, International Law Perspectives, Cambridge University Press, Cambridge, 2006, p. 35.

${ }^{31}$ Théodore Christakis, "The State as a 'Primary Fact': Some Thoughts on the Principle of Effectiveness", in: M. G. Kohen (ed.), Secession, International Law Perspectives, University Press, Cambridge, 2006, pp. 138-170.

32 Post-Soviet Frozen Conflicts: A Challenge For European Security, Warsaw Institute Special Report, 14 March 2019.

зз Занимљиви су најновији случајајеви „замрзнутих конфликта“ in statu nascendi, у областима украјинске регије Донбас - Доњецку и Луганску, које су након политичке кризе у Украјини 2013. године прогласиле независност 22. маја 2014. године. Пошто је криза ексалирала у оружани сукоб, у Минску је септембра 2014. године, у присуству представника ОЕБС-а, потписан споразум о примирју. Доњецк и Луганск су потом под утицајем проруских снага склопили споразум о уједињењу и формирању конфедерације „Новорусије“, која није добила међународно признање. Коначно политичко решење о статусу ових подручја није постигнуто и поред чињенице да је у фебруару 2015. године, постигнут мировни споразум (Минск 2), уз гаранције Украјине, Немачке, Француске и Руске Федерације. Ваља још уочити и да је и Крим, који је такође био у саставу Украјине, прогласио независност и присаједињење Руској Федерацији у марту 2014. године. С обзиром на чињеницу да је до 1954. године, када је уступљен Украјини, Крим био у саставу Совјетске Социјалистичке Републике Русије, закључењем међусобног споразума од 18. марта 2014. године, Крим је заједно са стратешки важним градом Севастопољем „ретроцедиран“ у састав Руске Федерације. Видети: „О подписании Договора между Российской Федерацией и Республикой Крым о принятии в Российскую Федерацию Республики Крым и образовании в составе Российской Федерации новых субъектов", Распоряжение Президента Российской Федерации от 17.03.2014 № 63-pп, retrieved from, https://web.archive.org/ web/2014031 8095051/http://pravo.gov.ru:8080/page.aspx?92062. Међутим, Украјина није прихватила и 
конфликата" има доста, а међу значајнијим су случајеви који се односе на Абхазију, Јужну Осетију, Нагорно-Карабах и Придњестровље. ${ }^{33}$

\section{Абхазија}

Абхазија је у СССР-у имала статус Совјетске Социјалистичке Републике од 1921. до 1931. године. Као једна од територијално-административних јединица поред Аџарске АССР, Јужноосетинске аутономне области Абхазија је ушла у састав ССР Грузије 1922. године. Грузија је уз Јерменију и Азербејџан била у саставу Закавкаске Социјалистичке Федеративне Републике која је постојала до 1936. године. У току 1931. године статус Абхазије био је измењен, тако да је она постала АССР. Рестриктивна националистичка политика према Абхазији, коју је спроводила Грузија у периоду пре и након Другог светског рата, довела је до дискриминације и до промене демографске структуре становништва. Последњих година совјетске власти дошло је до заоштравања односа Абхазије са Грузијом. Наиме, у марту 1989. године абхашки националисти су у Декларацији из Лихнија захтевали званично успостављање одвојене ССР. Пошто овај захтев није прошао, избили су грађански сукоби. Након њиховог окончања криза се пренела у државне институције. Обнављање грузијске државности изведено је након одржавања референдума од 31. марта 1991. године, проглашавањем независности 9. априла исте године. Пре тога, 17. марта 1991. године, Абхазија је гласала на савезном референдуму о очувању и обнављању СССР-а. Овај чин је додатно утицао на погоршавање међусобних односа. Криза је ескалирала након што је Абхазија једнострано прогласила независност 23. јула 1992. године. Већ у августу 1992. године, грузијске трупе су преузеле контролу над Сухумијем. Абахазијске власти су се повукле на резервне положаје у Гудауту, на северу одакле су организовале оружани отпор. У 1993. години, абхазијске снаге успеле су да поврате окупирана подручја. Исте године, Савет безбедности Уједињених нација резолуцијом 858 формирао је посматрачку мисију за Грузију (UNOMIG), чији је мандат

признала наведене акте. Уједињене нације су резолуцијом Генералне скупштине 68/262 од 27. марта 2014. године, потврдиле своју приврженост очувању територијалног интегритета и суверенитета Украјине у међународно признатим границама. Видети: Marco Longobardo, The Use of Armed Force in Occupied Territories, University Press, Cambridge, 2018, pp. 17, etc. 
временом прошириван. ${ }^{34}$ Након што је уз посредовање Специјалног представника Генералног секретара Уједињених нација, у мају 1994. године, у Москви постигнут споразум о прекиду ватре, у јуну су оружане снаге Русије у оквиру мировне мисије ЗНД (CISPKF) биле размештене дуж линије раздвајања две зараћене стране. У току примирја, стране су износиле различите предлоге о решавању спорне ситуације. Тако је, почетком маја 2006. године, руководство Абхазије објавило мировни план који је предвиђао „фундаментално нове, добросуседске односе“ између Абхазије и Грузије као независних држава. Грузијска мировна иницијатива објављена је у јуну исте године, са понудом „широког унутрашњег суверенитета“ Абхазије, заснованог на принципима федерализма. Оба плана су пропала, а успостављено примирје било је нарушено упадом грузијских трупа у Кодорску клисуру. Ситуација је додатно погоршана када је Грузија најавила да неће дозволити мировној мисији ЗНД-а да патролира Кодурском клисуром, што се због одбијања руске стране није десило. Коначан прекид примирја уследио је у августу 2008. године, када је у петодневном рату Грузија покушала војном силом да поврати подручје Абхазије. Томе се супротставила Русија, чија је решеност да одбрани Абхазију довела до успостављања de facto ентитета - „Републике Абхазије“." Покушаји медијације подвођени под окриљем Уједињених нација тако нису довели до значајнијих резултата, а мандат посматрачке мисије Уједињених нација је због руског вета у Савету безбедности окончан у јуну 2009. године. ${ }^{36}$

\section{Јужна Осетија}

Јужна Осетија је имала статус аутономне области у оквиру Грузије као централне ССР Јужног Кавказа. Овај статус, који је установљен током 1922. године, трајао је све до проглашења независности 21. децембра 1991.

\footnotetext{
${ }^{34}$ United Nations Security Council Resolution 858. S/RES/858(1993), 24 August 1993.

${ }^{35}$ Русија је признала независност Републике Абхазије 26. августа 2008. године. Након тога, Абхазију су признале још и Никарагва, Венецуела, Науру, Вануату, Тувалу и Сирија. Јужна Осетија и Придњестровље такође су признале Републику Абхазију.

${ }^{36}$ Међутим, специјализоване агенције Уједињених нација наставиле су да раде у региону на мирном решавању спора и изградњи међусобног поверења. Видети: Giorgi Jangiani, "Role of United Nations in Georgia Abkhaz Conflict", in: Sergi Kapanadze et al. (eds), Lectures Note on Abkhazia, Georgia, Georgia, GRASS, 2015.
} 
године. У току 1989. године, Јужна Осетија је изнела захтев за преобликовањем аутономног статуса у АССР. Истовремено је тражила и припајање Северној Осетији. Реагујући на захтев, централне грузијске власти донеле су низ мера којима су дискриминисале осетску националну заједницу у погледу остваривања грађанских и политичких права. То је изазвало контрареакцију Јужне Осетије, која је у септембру 1990. године прогласила независност. Грузија је на овај чин одговорила укидањем аутономије Јужне Осетије. Даља ескалација политичке кризе довела је до оружаних сукоба који су трајали до 1992. године, када је у јуну у Сочију потписан споразум о прекиду ватре и установљавању мировне мисије састављене од руских, грузијских и осетских снага (Joint Peacekeeping Forces group - JPKF). ${ }^{37}$ Извршавање функција мировне мисије надгледала је Заједничка контролна комисија са посматрачима ОЕБС-а, који су настојали да олакшају преговоре о регулисању спорних статусних питања и да елиминишу изворе напетости између зараћених страна. Након „револуције ружа“ 2003. године, када је дошло до смене власти у Грузији (уместо Едварда Шеварнадзеа дошао је западно оријентисани председник Михаил Саакашвили), успостављање територијалног интегритета Грузије постаје приоритетан задатак. До политичке дестабилизације и нарушавања мира у региону дошло је након што је Грузија одбила да Заједничка контролна комисија има одлучујућу улогу у мировном процесу. Када је Јужна Осетија организовала референдум о независности 2006. године, безбедносна ситуација је била погоршана. Конфликт је ескалирао 8. августа 2008. године, када су грузијске трупе напале осетске положаје, што је довело до војне интервенције Русије која је у муњевитој акцији успела да поврати мир и стабилност у региону. ${ }^{38}$ Целокупна територија Јужне Осетије потом је стављена под контролу јужноосетијске владе. Зараћене стране прихватиле су споразум о прекиду ватре 12. августа 2008. године. У септембру исте године, стране су се сагласиле да отпочну преговоре око регулисања статуса спорног подручја. Статус Јужне Осетије није међународноправно дефинисан и поред чињенице да је Јужна Осетија

${ }^{37}$ Dennis Sammut, Nikola Cvetkovski, Confidence Building Matters: The Georgia-South Ossetia Conflict, Verification Technology Information Centre, London, 2006, pp. 14, etc.

${ }^{38}$ Сматра се да је непосредни повод за овај сукоб био испровоциран од стране западних сила које су подржале независност Косова и Метохије и дале отворену подршку Украјини и Грузији за пријем у НАТО. Видети: Matthias Kuster, „Грузијско-руски рат 2008. године“, Војно дело, лето 2014, стр. 27. 
добила међународно признање од стране Русије и још неколико других земаља. Јужна Осетија се као „Република Јужна Осетија“ у међународним односима третира за de facto ентитет и зону „замрзнутог конфликта“. 39

\section{Нагорно-Карабах}

Нагорно-Карабах је у време СССР-а имао статус аутономне области у оквиру ССР Азербејџан. Иако на овом историјском подручју Закавказја и територијалној енклави живи доминантна већина јерменског становништва, подручје је одлуком совјетске Комисије за Кавказ, из 1921. године, додељено Азербејџану. Током читавог периода совјетске власти спровођени су различити облици репресије над локалним Јерменима, што је узроковало настанак националистичких покрета који су задржали јаку жељу да се припоје суседној ССР Јерменији. ${ }^{40}$ У време Горбачова и политике „гласности и перестројке“, Нагорно-Карабах је затражио уједињење са Јерменијом 20. фебруара 1988. године. Међутим, тај захтев био је одбијен од савезних власти са аргументом да би такав преседан био противуставан и да би могао покренути „лавину“ отцепљења других аутономних области или регија унутар СССР-а. С друге стране, Нагорно-Карабах се позивао на примену принципа самоопредељења које је такође било дубоко утемељено у последњем совјетском Уставу из 1977. године. Супротстављеност ставова временом је довела до ескалације међуетничких сукоба између Јермена и Азера у којима су се умешале и совјетске оружане снаге. Међутим, ова интервенција није допринела смиривању ситуације, већ је учврстила уверење Јермена да се решење за Нагорно-Карабах може постићи једино насилним путем. Након што је Азербејџан прогласио независност од СССР-а - 30. августа 1991. године, дошло је до сецесије области Нагорно-Карабах, која је након одржаног референдума - 10. децембра 1991. године, такође прогласила независност. Ова ситуација допринела је интензивирању оружаног сукоба који се завршио са више успеха за јерменску страну.

\footnotetext{
39 Поред Русије, независност Републике Јужне Осетије признале су још Никарагва, Венецуела, Науру и Тувалу.

${ }^{40}$ Између Нагорно-Карабаха и Јерменије, у периоду од 1923. до 1930. године, налазио се аутономни округ Црвени Курдистан у коме је било већинско курдистанско становништво. После укидања овог округа, Курди су насилно депортовани у Казахстан, а простор је ушао у састав Нагорно-Карабаха.
} 
Конфликт у којем су се неретко мешале и треће стране, трајао је све до 16. маја 1994. године, кад је уз посредовање ОЕБС-а дошло до закључења споразума о примирју. ${ }^{41}$ Примирје није било учвршћено неким конкретним мировним споразумом уз посредовање међународне заједнице, па све до данашњих дана долази до његовог нарушавања што дестабилизује читав регион Кавказа. Кавказ, иначе, заузима простор између Каспијског и Црног мора и представља раскрсницу између Блиског истока, Турске, Ирана и Русије. Уз његов важан геостратешки положај, Кавказ обилује енергетским потенцијалима због чега представља важну детерминанту у спољној политици великих сила, као и у активностима регионалних међународних организација у којима оне имају значајну улогу. Тако су, у решавању овог конфликта, на посредан или непосредан начин инволвиране Русија, Сједињене Америчке Државе, Иран, Турска и друге чланице НАТО-а, Европска унија, ОЕБС и Организација исламске конференције. Велика пажња око решавања конфликта у Нагорно-Карабаху није утицала на чврст став Уједињених нација да у циљу очувања политичке стабилности кавкаског региона потврде територијални интегритет Азербејџанске Републике. Тиме је, у ствари, светска организација истакла да не прихвата примену „рекурзивне сецесије", тј. накнадног остваривања права на спољно самоопредељење народа настањених на просторима бивших ССР-а, након стицања њихове независности. ${ }^{42}$ Лавирајући између различитих супротстављених интереса на подручју Нагорно-Карабаха, сличан приступ усвојиле су и друге међународне организације попут Савета Европе који је потврдио неповредивост наслеђених граница Азербејџана из времена СССР-а, као и Европске уније која је одбацила могућност стицања независности Нагорно-Карабаха након одржаног референдума 2006. године. Пошто је Нагорно-Карабах важан геостратешки правац на Кавказу, спољна пенетрација ће вероватно остати трајна одредница за утвђивање његовог коначног статуса. Досадашњи

\footnotetext{
41 Примирје је потписано посредовањем тзв. Минск групе коју су чиниле Русија, Јерменија, Азербејџан, Сједињене Америчке Државе, Турска, Француска, Немачка, Италија, Шведска и Чешка. Видети: Richard Allen Greene, "As Minsk Group Marks 10 Years, Karabakh Peace Appears More Elusive Than Ever", Internet: http://www.azer.com/aiweb/categories/ karabakh/karabakh_duscussions/karabakh_greene.html

${ }^{42}$ Савет безбедности је овакав став потврдио у резолуцијама 822, 853, 874 и 884 . Генерална Скупштина се у сличном тону изјаснила у резолуцијама 49/13, 57/298 и 62/243 тражећи уједно повлачење јерменских снага са окупираних азербејџанских територија.
} 
предлози о успостављању различитих видова територијално-политичке аутономије унутар Азербејџана нису били прихваћени од Нагорно-Карабаха, али и од других заинтересованих актера (Јерменије, пре свега). Стога, уз Абхазију, Јужну Осетију и Приднестровље, Нагорно-Карабах представља зону „замрзнутог конфликта" и de facto ентитет без јасно опредељене будућности у регионалним и ширим - међународним односима.

\section{Придњестровље}

На самом почетку конституисања СССР-а, 1924. године, молдавске области са Придњестровљем ушле су у састав АССР Молдавије које су биле саставни део ССР Украјине. Као веома уска област између реке Дњестар и Украјине, Придњестровље је имало нарочити значај за СССР будући да је као територијални појас требало да има улогу „санитарног кордона“ према молдавским областима и Румунији. Након што је закључен МолотовРибентроп пакт о ненападању између СССР и нацистичке Немачке 1939. године, ово подручје заједно са Бесарабијом припало је совјетској интересној сфери. У јуну 1940. године, Румунији је испостављен совјетски ултиматум за предају подручја Бесарабије (уз Северну Буковину и област Херца). По уступању подручја, СССР је један његов део, који није ушао у састав Одешке области ССР Украјине, припојио АССР Молдавије. Потом је формирао ССР Молдавије у чији састав су ушле области девет бесарабијских ујезда и шест рејона Левобрежног Дњестра који су до тог момента били у саставу ССР Украјине и АССР Молдавије. ${ }^{43}$ У току Другог светског рата Румунија је успела да поврати све анектиране територије тзв. Транснистрије (између Јужног Буга и Дњестра уз украјинске градове Балту, Винице и Одесу). Крајем Другог светског рата совјетска армија је ослобађајући простор југоисточне Европе повратила све заузете области у Румунији. Тако су и границе Молдавске ССР остале непромењене све до деведесетих година 20. века, када је дошло до промена на унутрашњем политичком плану спровођењем Горбачовљеве реформистичке политике. У Молдавији почињу да јачају прорумунске националистичке тежње и спроводе се мере дискриминације према већинском словенском становништву. Као важно и истурено геостратешко подручје СССР-а, Придњестровље проглашава независност 2. септембра

${ }^{43}$ Срећко Ђукић, Крај СССР-а и Русија, Службени гласник, Београд, 2011, стр. 498. 
1990. године, што доводи до правног и политичког спора са Молдавијом. Након што је Молдавија прогласила независност 27. августа 1991. године, избијају оружани сукоби који је трају до закључења споразума о прекиду ватре 21. јула 1992. године. Као део тог споразума, тространа рускомолдавско-придњестровска Контролна комисија надгледа извршење безбедносних аранжмана у демилитаризованој зони која обухвата двадесет локалитета са обе стране реке Дњестар. Иако је примирје одржано уз присуство руских мировних снага, политички статус територије Придњестровља остао је нерешен. Претходни покушаји решавања овог питања, уз посредовање Русије (тзв. Козак планови о федерализацији Молдавије), нису успели. Придњестровље је остало чврсто на идеји сецесионизма и независности, па чак и присаједињења Руској Федерацији. С друге стране пак Молдавија, која се геостратешки налази између Истока и Запада и која је пуноправни члан ЗНД-а и активни партнер Европске уније, настоји да задржи своју неутралну позицију не одустајући од поштовања принципа територијалног интегритета и неповредивости државних граница. Препуштање постизања коначног решења о статусу Придњестровља у формату „5+2“ између Русије, Украјине и ОЕБС-а (уз присуство посматрача Европске уније и Сједињених Америчких Држава), такође није довело до значајнијих помака. Позиције Тираспоља и Кишњева остале су непромењене све до данашњих дана. „Придњестровска Молдавска Република“ (какав је званичан назив спорне територије), и даље је зона „замрзнутог конфликта“ и de facto ентитет кога су признала три ентитета са једнаким статусом Абхазија, Јужна Осетија и Нагорно-Карабах. ${ }^{44}$

\section{Закључна разматрања}

Трансформисана глобална хијерархија, након окончања Хладног рата, довела је до низа сукцесивних сецесија ССР-а од СССР-а, што је за крајњи резултат имало дисолуцију совјетске федерације. Будући да је реализација

\footnotetext{
${ }^{44}$ Сва четири de facto ентитета настала на постсовјетском подручју учлањена су у тзв. Заједницу за демократију и права народа познатију под називом „Заједница непризнатих држава", (Содружство непризнанних государств, СНГ-2), која представља међународну организацију која уједињује пара-државне ентитете, а који имају ограничено признање међународне заједнице.
} 
права народа на самоопредељење до отцепљења била једна од најважнијих детерминанти које су одређивале правац кретања овог политичког процеса, у студији је посвећена посебна пажња испитивању његове легалности. С тим у вези, утврђено је да предвиђена решења у унутрашњем праву СССР-а нису била сасвим у складу са међународним правним стандардима. Наиме, у републикама које су решиле да се отцепе од СССР-а (изузев балтичких република код којих је правни наслов за отцепљење био другачији, јер се није позивао на уставне одредбе већ на противправну анексију), није обезбеђен адекватан институционални механизам, нити одговарајући оквир који би пружио довољне правне гаранција за иступање из федерације. Унутрашња законодавства федералних јединица притом нису водила довољно рачуна о вољи различитих етничких и националних заједница, које су поред већинских „народа“ због свог аутономног статуса у држави претходници такође имале право да захтевају да се изјасне о свом будућем политичком статусу, облику владавине, економском, социјалном и културном развоју и индивидуалном учешћу у вршењу власти. У сврху одржавања политичке стабилности, принцип територијалног интегритета и неповредивости наслеђених међурепубличких граница однео је превагу над принципом равноправности народа, што је у периоду након стицања независности неких ССР-а довео до тзв. рекурзивних сецесија и до настанка de facto државних ентитета. Ови ентитети per se, представљају зоне „замрзнутих конфликта“ које прете да угрозе међународни мир и безбедност. Отуд, ове зоне у великој мери представљају изазов за успостављање међународних веза у региону Источне Европе и Јужног Кавказа. Због недостатка ефективне власти над целокупним државним подручјем, државе попут Грузије, Молдавије и Украјине нису у могућности да воде независну унутрашњу и спољну политику. На подручјима ових држава успостављени de facto ентитети уживају подршку Руске Федерације, чији стратешки интереси не дозвољавају укључење ових подручја у оквире ширих евро-атлантских интеграција. ${ }^{45}$ Притом, НАТО и Европска унија не дозвољавају чланство државама које нису у стању да врше пуну ефективну власт над својим територијама. Због недостатка воље у регулисању статуса ових подручја мировни процеси дуго трају, што у перспективи демобилише напоре

\footnotetext{
45 Драган Петровић, Геополитика постсовјетског простора, Прометеј Нови Сад, Институт за међународну политику и привреду, Београд, 2008, стр. 1-250.
} 
усмерене ка постизању политички одрживих решења. Тренутно прихваћени status quo отуд јесте реалност са којом нове државе, али и отцепљена подручја на простору бившег СССР-а, морају да живе. ${ }^{46}$

\section{Библиографија}

"Alma-Ata Declaration", International Legal Materials, 1992, No. 31.

Beissinger, Mark R., "The intersection of Ethnic Nationalism and People Power Tactics in the Baltic States", in: Adam Roberts; Timothy Garton Ash (eds.), Civil resistance and power politics: the experience of non-violent action from Gandhi to the present, Oxford University Press, Oxford, 2009.

Blum, Yehuda Z., "Russia takes over the Soviet Union's Seat at the United Nations", European Journal of International Law, 1992, Vol. 3, No. 2.

"Charter of the Commonwealth of Independent States", Minsk, 22 January 1993.

Christakis, Théodore, "The State as a 'Primary Fact': Some Thoughts on the Principle of Effectiveness", in: M. G. Kohen (ed.), Secession, International Law Perspectives, University Press, Cambridge, 2006.

Doehring, Karl, "Self-Determination”, in: Bruno Simma (ed.), The Charter of the United Nations: A Commentary, Oxford: University Press, 2002, Vol. I.

"Declaration by the Heads of State of the Republic of Belarus, the Russian Soviet Federative Socialist Republic; Agreement on the Establishment of the Commonwealth of Independent States, between the Republic of Belarus, the Russian Federation (RSFSR) and Ukraine", Minsk, 8 December 1991, International Legal Materials, 1992, No. 31.

"Declaration on the Guidelines on the Recognition of New States in Eastern Europe and in the Soviet Union", UN Security Council Document S/23293, 17 December 1991, Annex II (1992), International Legal Materials, Vol. 31.

Димитријевић, Душко, „Међународноправни токови сецесије држава“, у: Јелена Перовић Вујачић, Унификација права и правна сигурност, Копаоничка школа природног права - Слободан Перовић, Београд, 2020.

\footnotetext{
${ }^{46}$ Ана Јовић Лазић, Ивона Лађевац, „Замрзнути сукоби и преговарачки процеси у региону Јужног Кавказа“, Међународна политика, 2013, бр. 1152, стр. 55-73.
} 
Димитријевић, Душко, „Сецесија држава у доктрини и пракси међународног права", у: Зоран Кнежевић, Коста Чавошки (уред.), Сецесија са становишта унутрашњег и међународног права и њене политичке последице, Српска академија наука и уметности, Београд, 2020.

Димитријевић, Душко, Међународно право сукцесије држава: Сукцесија државне имовине с посебним освртом на сукцесију СФР Југославије, Институт за међународну политику и привреду, Београд, 2007.

Димитријевић, Душко, „Настанак и функционисање међудржавних форума за сарадњу у Европи: један правни преглед", Драган Ђукановић (ур.), Међудржавни форуми у Европи, Институт за међународну политику и привреду, Београд, 2007.

Ђукић, Срећко, Крај СССР-а и Русија, Службени гласник, Београд, 2011.

“Frontier Dispute (Burkina Faso v. Mali)", International Court of Justice Reports, 1986.

Grant, T. D., The Recognition of States: Law and Practice in Debate and Evolution, Praeger, Westport, 1999.

Greene, Richard Allen, "As Minsk Group Marks 10 Years, Karabakh Peace Appears More Elusive Than Ever, Internet: http://www.azer.com/aiweb/categories/ karabakh/karabakh_duscussions/karabakh_greene.html

Hazard, John N., Soviet Republics in International Law, in: R Bernhardt (ed.), Encyclopedia of Public International Law, Max Planck Institute for Comparative Public Law and International Law., Amsterdam: North-Holland, 2002.

Jangiani, Giorgi, "Role of United Nations in Georgia Abkhaz Conflict", in: Sergi Kapanadze et al. (eds), Lectures Note on Abkhazia, Georgia, Georgia, GRASS, 2015.

Јовичић, Миодраг, Велики уставни системи, елементи за једно упоредно уставно право, ИРО Светозар Марковић, Београд, 1984.

Јовић Лазић, Ана, Лађевац, Ивона, Замрзнути сукоби и преговарачки процеси у региону Јужног Кавказа", Међународна политика, 2013, бр. 1152.

Касезе, Антонио, Самоодређење народа, Службени гласник, Београд, 2011. Kherad, Rahim, "La reconnaissance internationale des Etats Baltes", Revue Generale de Droit International Public, 1992, No. 96.

Kuster, Matthias „Грузијско-руски рат 2008. године“, Војно дело, лето 2014. 
Longobardo, Marco, The Use of Armed Force in Occupied Territories, University Press, Cambridge, 2018.

Müllerson, Rein, "The Continuity and Succession of States, by reference to the Former USSR and Yugoslavia", International and Comparative Law Quarterly, 1992, Vol. 42.

Müllerson, Rein, Law and Politics in the Recognition of New States, International Law: Rights and Politics, Routladgle, London, 1994.

„О подписании Договора между Российской Федерацией и Республикой Крым о принятии в Российскую Федерацию Республики Крым и образовании в составе Российской Федерации новых субъектов", Распоряжение Президента Российской Федерации от 17.03.2014 № 63рп, Internet, https://web.archive.org/web/20140318095051/ http://pravo. gov.ru:8080/page.aspx?92062.

Павковић, Александар, Радан, Петар, Стварање нових држава: Теорија и пракса отцепљења, Службени гласник, Београд, 2008.

Pellet, Alain, "The Opinions of the Badinter Arbitration Committee: A Second Breath for the Self-Determination of Peoples", European Journal of International Law 1992, Vol. 3, No. 1.

Петровић, Драган, Геополитика постсовјетског простора, Прометеј Нови Сад, Институт за међународну политику и привреду, Београд, 2008.

Ponomarenko, Illia, "Ukraine withdraws all envoys from CIS bodies", Kyiv Post, 19 May 2018.

Post-Soviet Frozen Conflicts: A Challenge For European Security, Warsaw Institute Special Report, 14 March 2019.

"Protocol to the Agreement on the Establishment of the Commonwealth of Independent States signed on December 8, 1991 at the city of Minsk, by the Republic of Belarus, the Russian Federation (RSFSR) and Ukraine, between the Republic of Azerbaijan, Republic of Armenia, Republic of Belarus, Republic of Kazakhstan, Russian Federation, Republic of Tajikistan, Turkmenistan, Republic of Uzbekistan and Ukraine," Alma-Ata, 21 December 1991, International Legal Materials, 1992, No. 31.

Првуловић, Љубивоје, „Неки политички, војни и национални проблеми на тлу бившег Совјетског Савеза", Међународни проблеми, 1997, бр. 3-4.

Rich, Roland, "Recognition of States: The Collapse of Yugoslavia and the Soviet Union", European Journal of International Law, 1993, Vol. 4, No. 1. 
Sammut, Dennis, Cvetkovski, Nikola, Confidence Building Matters: The GeorgiaSouth Ossetia Conflict, Verification Technology Information Centre, London, 2006.

Schweisfurth, Theodor, Soviet Union, Dissolution, in: R. Bernhardt (ed.), Ecyclopedia of Public International Law, Amsterdam: Elsevier, 2000, Vol. IV.

Thines, Serge, From Soviet federalism to the creation of the Commonwealth of Independent States, University of Luxembourg, CVCEeu, 2016, Internet: https://www.cvce.eu/obj/from_soviet_federalism_to_the_creation_of_the commonwealth_of_independent_states_cis-en-caa796f9-24fo-4e25-98da4e98b20f18c8.html

Tomuschat, Christian, "Secession and Self-Determination", in: Marcelo G. Kohen (ed.), Secession, International Law Perspectives, Cambridge University Press, Cambridge, 2006.

Trancredi, Antonello, "Neither Athorized nor Prohibited? Secession and International Law after Kosovo, South Ossetia and Abkhazia", Italian Yearbook of International Law, 2008, No. 18.

United Nations Security Council Resolution 858. S/RES/858(1993), 24 August 1993.

Voitovich, Sergei A.,"The Commonwealth of Independent States: An Emerging Institutional Model", European Journal of International Law, 1993, Vol. 4, No. 3.

Yakemtchouk, Romain, Les Républiques baltes en droit international. Echec d'une annexion opérée en violation du droit des gens, Annuaire Français de Droit International, 1991, No. 37. 


\section{SECESSIONIST PROCESSES - FACTORS OF PRESERVATION OR DISTURBANCE OF PEACE AND SECURITY IN THE FORMER USSR SPACE}

Abstract: The Cold War ended the long-running rivalry between the East and the West, as well as the seventy-year-old ideological conflict in which capitalism triumphed over communism. The transformed global hierarchy led to a new political imbalance, which resulted in not only a flourishing of nationalism, intolerance, but also revenge and political revisionism. The new world order marked the end of the great socialist federations, primarily the Union of Soviet Socialist Republics (USSR), which entered the process of state disintegration (dissolution) in the early 1990s. The dissolution of the USSR was a consequence of "more or less" peaceful successive secessions, which led to the disappearance of the Soviet state and the formation of the Commonwealth of Independent States (CIS). The following study provides appropriate explanations regarding the development of Soviet statehood and the political processes that led to successive secessions and the independence of the former Soviet Socialist Republics (SSR). The study also contains an international legal analysis of the inconsistent application of the right to self-determination, which has resulted in centrifugal political processes and so-called recursive secession in the areas of some newly independent states, causing the creation of de facto entities and zones of "frozen conflicts", which latently threaten international peace and security.

Keywords: USSR, secession, dissolution, recursive secession, de facto state entities, zones of frozen conflicts, peace and security. 